\title{
Studi Tentang Perbandingan Penerapan E-Business dalam Meningkatkan Efisiensi Biaya Operasional dan Kaitanya Dengan Tingkat Laba Perusahaan \\ (Studi Kasus Penggunaan Layanan $e$-Toll Card pada PT Jasa Marga Tbk. Cabang Purbaleunyi)
}

\author{
Study About Comparison Of E-Business Implementation In Improving Operational \\ Cost Efficiency And Relationship With Company's Profit Level \\ (Case Study Using E-Toll Card in PT Jasa Marga Tbk. Purbaleunyi Branch) \\ ${ }^{1}$ Veina Nur'aida Wulandari, ${ }^{2}$ Nurleli, ${ }^{3}$ Rini Lestari \\ Akuntansi, Universitas Islam Bandung \\ Jl. Tamansari No.1 Bandung, 40116 \\ email:. ${ }^{1}$ veinanuraida@gmail.com, ${ }^{2}$ lelinur@yahoo.com, ${ }^{3}$ unirinilestari@gmail.com
}

\begin{abstract}
The objectives of State enterprises engaged in the management, operation and scheduling of toll roads are always trying to improve customer service by creating creative, reliable \& quality service products, one of which is electronic card (E-Toll Card). This study aims to describe the implementation of E-Toll Card in improving the efficiency of operational costs and performance with the level of corporate earnings. Descriptive data analysis is done for implementation and measurement. The results of research conducted on the application of E-Toll Card in Purbaleunyi Branch can be said to be very adequate seen from the company's commitment to customer needs. The development of operational cost efficiency and capacity with the level of profit. Meanwhile, after implementation, there is inefficiency due to the transition of payment transactions to non-cash. This results in the cost of funding costs, but the impact on the optimal level. For that it is necessary to make a policy based on what has been done so efficiently can really be achieved well.
\end{abstract}

\section{Keywords: Operational Cost, Efficiency, E-Toll Card, Profit}

\begin{abstract}
Abstrak. Tujuan perusahaan Negara (BUMN) yang bergerak dalam bidang penyelenggaraan, pengelolaan dan pemeliharaan jalan tol selalu berusaha meningkatkan pelayanan terhadap pelanggan dengan menciptakan produk layanan kreatif, handal \& berkualitas, salah satunya adalah penerbitan kartu elektronik (E-Toll Card). Penelitian ini bertujuan untuk mendeskripsikan penggunaan E-Toll Card dalam meningkatkan efisiensi biaya operasional dan kaitannya dengan tingkat laba perusahaan. Analisis data secara deskriptif dilakukan untuk menggambarkan penerapan E-Toll Card dan laporan keuangan yang berupa anggaran, realisasi biaya operasional dan laba untuk kemudian dilakukan perbandingan saat sebelum dan setelah penerapan. Hasil penelitian yang dilakukan terhadap penerapan E-Toll Card di Cabang Purbaleunyi dapat dikatakan sangat memadai dilihat dari adanya komitmen perusahaan terhadap kebutuhan pelanggan. Perkembangan efisiensi biaya operasional dan kaitannya dengan tingkat laba sebelum adanya penerapan sudah efisien sehingga tingkat laba tercapai. Sedangkan saat setelah penerapan, terjadi inefisiensi akibat adanya peralihan transaksi pembayaran menjadi non tunai. Ini berakibat pada munculnya biaya-biaya diluar anggaran perusahaan, namun berimbas kepada meningkatnya tingkat laba optimal.
\end{abstract}

Kata kunci: Biaya Operasional, Efisiensi, E-Toll Card, Laba 



\section{A. Pendahuluan}

Perkembangan teknologi informasi dan juga internet tumbuh sangat cepat dan pesat bahkan semakin luas, seluruh aspek kehidupan manusia terkena dampak penggunaannya. Tidak dapat dipungkiri bahwa peran teknologi saat ini menjadi sangat dominan bagi perkembangan perusahaan, gelombang lainnya bisnis digital atau berbasis teknologi informasi telah melahirkan fenomena bisnis baru.

Dalam dunia bisnis, untuk memuaskan kebutuhan stakeholders,shareholders dan melengkapi aplikasi suatu perusahaan maka muncul lah konsep tren bisnis baru yang dinamakan E-Business. Tren bisnis terbaru ini sudah tidak terlalu asing dalam lingkup organisasi maupun perusahaan (Chaffey, 2009: 35). Banyak orang mempertukarkan istilah E-Business dengan E-Commerce. Secara prinsip, pengertian E-Business jauh lebih luas dibandingkan dengan E-Commerce; bahkan secara filosofis, E-Commerce merupakan bagian dari E-Business (Combe, 2006: 11). Salah satu sub kajian dari E-Business yang saat ini baru muncul adalah berkembangnya transaksi online, yaitu dikembangkannya berbagai alat pembayaran yang menggunakan teknologi, dimana semula skema pembayaran tunai melalui uang kertas menjadi sistem pembayaran non-tunai yang tersimpan dalam media elektronik atau disebut juga Electronic Money (E-Money) (Indrajit, 2002:34).

Salah satu perusahaan yang meluncurkan produk pembayaran secara digital ini adalah PT Jasa Marga Tbk. Untuk mengatasi masalah kemacetan, antrean dan penumpukan kendaraan di setiap gerbang tol, PT Jasa Marga sebagai perusahaan penyedia layanan jalan bebas hambatan meluncurkan produk inovatif pada tahun 2009 untuk mengatasi kemacetan di gerbang tol yaitu Electronic Toll Card (Lukaman, 2017: 1). Pengguna E-Tollcard hanya perlu menempelkan kartu untuk membayar uang tol dalam waktu 4 detik, lebih cepat dibandingkan bila membayar secara tunai yang membutuhkan waktu 7 detik (Wahyudi, 2017). Kemunculan E-Toll card ini diharapkan mampu membantu masyarakat dalam kenyamanan dan keamanan bertransaksi serta memberikan manfaat bagi perusahaan ataupun organisasi guna menekan biaya operasional yang terlalu tinggi dibandingkan sebelum diluncurkannya produk tersebut (Amalia, Fanida 2017: 2).

Sebagaimana yang dikemukakan oleh Wijaya dan Safitri (2013: 2) bahwa suatu perusahaan tentunya menginginkan suatu tingkat pertumbuhan yang baik, yang tercermin dalam pencapaian tingkat laba yang maksimal dan untuk bisa mencapai laba yang maksimal perusahaan mempunyai cara yang tepat dengan cara mengendalikan biaya-biaya untuk keperluan operasional sehingga dapat dicapai efisiensi. Efisiensi dalam aktivitas operasional akan bermanfaat banyak bagi perusahaan karena dapat menunjang kelangsungan hidup perusahaan di masa yang akan datang. Karena pada umumnya tujuan didirikannya perusahaan adalah untuk memperoleh laba dan perusahaan selalu berusaha untuk meningkatkan profitabilitasnya (Santoso, 2017:2).

Berdasarkan uraian diatas penulis tertarik untuk mengetahui sejauh mana $E$-toll card yang dikeluarkan oleh PT Jasa Marga mampu meningkatkan efisiensi biaya operasional dan kaitannya dengan tingkat laba perusahaan, dengan membandingkan efisiensi biaya operasional sebelum dan setelah adanya penerapan layanan E-toll Card.

\section{B. Landasan Teori}

\section{Pengertian E-Business}

E-Business atau Bisnis Elektronik adalah transaksi bisnis atau pertukaran informasi yang dijalankan dengan menggunakan teknologi informasi dan komunikasi 

(Hansen dan Mowen, 2009:13). Penggolongan E-Business yang pada umumnya terjadi di Indonesia Menurut Suyanto (2003:13), yaitu Business to Business (B2B) dan Business to Consumer (B2C).

1. Business to Business (B2B)

Adalah sistem komunikasi bisnis on-line antar pelaku bisnis atau transaksi secara elektronik antar perusahaan yang dilakukan secra rutin dan dalam kapasitas produk yang besar.

2. Business to Consumer (B2C)

Merupakan sistem komunikasi bisnis antar pelaku bisnis dengan konsumen untuk memenuhi kebutuhan tertentu pada waktu tertentu.

\section{Pengertian E-Money (Elektronik Money)}

Peraturan Bank Indonesia No.11/12/PBI/2009 mengemukakan bahwa Uang Elektronik (electonic money) adalah uang yang digunakan dalam transaksi Internet secara elektronik.

\section{E-Toll (Elekornik Toll)}

Kartu Tol Elektronik merupakan bentuk modernisasi pelayanan yang dilakukan oleh PT Jasa Marga sebagai pengelola tol (Jasa Marga, 2012). Elektronik Toll (E-Toll) adalah sebuah program dalam bentuk layanan pembayaran tol secara elektronik yang berupa kartu elektronik digunakan untuk melakukan pembayaran masuk jalan tol di sebagian daerah Indonesia (Amalia, Fanida 2017: 4).

\section{Efisiensi Biaya Operasional}

Efisiensi adalah perbandingan output terhadap input atau jumlah output per unit. Dalam beberapa organisasi, efisiensi diukur dengan cara membandingkan biaya aktual dengan standar, dimana biaya-biaya tersebut harus dinyatakan dalam output yang diukur (Govindarajan, 2005:114).

Biaya Operasional dapat diartikan sebagai keseluruhan biaya-biaya komersil yang dikeluarkan untuk menunjang atau mendukung kegiatan atau aktivitas perusahaan untuk mencapai sasaran yang telah ditentukan (Mulyadi, 2009 : 84).

\section{Tingkat Laba}

Laba (income disebut juga earnings atau profit ) merupakan ringkasan hasil bersih aktivitas operasi usaha dalam periode tertentu yang di nyatakan dalam istilah keuangan. (Subramanyam, Wild, 2010:109).

\section{Metode Penelitian}

Metode penelitian yang digunakan dalam penelitian ini adalah metode deskriptif analitis dengan pendekatan kuantitatif. Penelitian ini menjelaskan gambaran tentang fenomena yang terjadi di dunia nyata dengan sejelas-jelasnya. Penelitian ini dilakukan pada PT Jasa Marga Tbk. Cabang Purbaleunyi. Teknik pengumpulan data dilakukan dengan menggunakan kuesioner dan wawancara. Kuesioner terdiri dari beberapa pernyataan tertutup. Kemudian hasil dari tanggapan responden diolah dan menghasilkan informasi berupa analisis statistik deskriptif.

\section{Hasil dan Pembahasan}

\section{Penerapan E-Business (E-Toll Card) PT Jasa Marga Tbk. Cabang Purbaleunyi}

Penelitian dilakukan pada PT Jasa Marga (Persero) Tbk Cabang Purbaleunyi Departemen TCM dan Departemen CDP. Penulis melakukan penelitian dengan menyebarkan kuesioner sebagai alat pengumpulan data. Pernyataan-pernyataan 

kuesioner berisi tentang Penerapan E-Business (E-Toll Card) yang sesuai dengan indikator, yang akan ditampilkan pada tabel hasil rekapitulasi tanggapan responden sebagai berikut :

Tabel 1

Rekapitulasi Tanggapan Responden mengenai Penerapan (E-Toll Card) pada PT Jasa Marga (Persero) Tbk Cabang Purbaleunyi

\begin{tabular}{|c|c|c|c|c|c|c|}
\hline $\begin{array}{c}\text { NO } \\
\text { PERNYATAAN }\end{array}$ & SKOR & $\begin{array}{c}\text { NO } \\
\text { PERNYATAAN }\end{array}$ & SKOR & $\begin{array}{c}\text { NO } \\
\text { PERNYATAAN }\end{array}$ & SKOR & TOTAL \\
\hline 1 & 40 & 6 & 42 & 11 & 49 & \\
\hline 2 & 43 & 7 & 43 & 12 & 50 & \\
\hline 3 & 48 & 8 & 47 & 13 & 50 & \\
\hline 4 & 42 & 9 & 48 & 14 & 42 & \\
\hline 5 & 50 & 10 & 48 & 15 & 45 & \\
\hline TOTAL & $\mathbf{2 2 3}$ & & $\mathbf{2 2 8}$ & & $\mathbf{2 3 6}$ & $\mathbf{6 8 7}$ \\
\hline
\end{tabular}

Sumber : Hasil Perhitungan

Berdasarkan Tabel 4.1 hasil perhitungan dari skor, maka didapat total skor responden sebesar 687, hasil tersebut dikatakan dengan persentase tanggapan responden mengenai penerapan E-Toll Card pada PT Jasa Marga (Persero) Tbk Cabang Purbaleunyi adalah sebagai berikut 687: $(5 \times 15 \times 10) \times 100 \%=91,6 \%$. Berdasarkan hasil diatas, maka penerapan E-Business (E-Toll Card) pada PT Jasa Marga (Persero) Tbk Cabang Purbaleunyi termasuk dalam kategori sangat memadai.

Tingkat EfisiensiBiaya Operasional Sebelum Adanya Penerapan Layanan EBusiness (E-Toll Card)

Dalam penelitian ini peneliti mendapatkan anggaran biaya operasional dengan realisasi nya selama 2 Bulan sebelum adanya penerapan serentak E-Toll Card.

Tabel 2

Biaya Operasional Sebelum Penerapan E-Toll Card PT Jasa Marga (Persero) Tbk Cabang Purbaleunyi

\begin{tabular}{|c|c|r|r|r|c|}
\hline NO & URAIAN & ANGGARAN & REALISASI & PROPORSI & KET. \\
\hline 1 & Beban Pengumpulan Tol & $4,223,441,103$ & $4,101,853,485$ & 0.9712 & Efisien \\
\hline 2 & Beban Pelayanan Pemakai Jalan & $4,592,209,268$ & $4,252,111,118$ & 0.9259 & Efisien \\
\hline 3 & Beban Pemeliharaan Aktiva Jalan & $2,105,543,545$ & $2,021,883,661$ & 0.9603 & Efisien \\
\hline & TOTAL & $\mathbf{1 0 , 9 2 1 , 1 9 3 , 9 1 6}$ & $\mathbf{1 0 , 3 7 5 , 8 4 8 , 2 6 4}$ & $\mathbf{0 . 9 5 2 5}$ & Efisien \\
\hline
\end{tabular}

Sumber : PT Jasa Marga (Persero) Tbk Cabang Purbaleunyi Tahun 2017

Berdasarkan hasil perhitungan sebelum adanya penerapan E-Toll Card terjadi efisiensi biaya karena realisasi pada periode ini tidak melebihi anggaran yang dibuat oleh perusahaan, dimana perusahaan menganggarkan biaya atau beban operasi sebesar 10,921,193,916 dengan realisasi yang terpakai sebesar 10,375,848,264. Efisiensi biaya 

operasional yang terjadi pada periode ini disebabkan oleh realisasi pemakaian biaya operasional yang sesuai dengan anggaran yang dibuat oleh perusahaan dengan proporsi sebesar 0.9525 .

\section{Tingkat Laba Sebelum Adanya Penerapan Layanan E-Business (E-Toll Card)}

Pengukuran besarnya laba tergantung pada besarnya pendapatan dan biaya. Analisis dilakukan terhadap Pendapatan dan Beban saat 2 Bulan Sebelum penerapan E-Toll Card.

Tabel 3

Tingkat Laba Sebelum Penerapan E-Toll Card

\begin{tabular}{|c|l|r|}
\hline NO & \multicolumn{1}{|c|}{ URAIAN } & \multicolumn{1}{c|}{ JUMLAH } \\
\hline $\mathbf{1}$ & Pendapatan Tol & $194,471,282,144$ \\
\hline $\mathbf{2}$ & Pendapatan Non Tol & $2,124,398,181$ \\
\hline & Total Pendapatan & $\mathbf{1 9 6 , 5 9 5 , 6 8 0 , 3 2 5}$ \\
\hline $\mathbf{3}$ & Beban Sdm & $12,550,186,727$ \\
\hline $\mathbf{4}$ & Beban Operasi & $\mathbf{1 0 , 3 7 5 , 8 4 8 , 2 6 4}$ \\
\hline $\mathbf{5}$ & \multicolumn{1}{|c|}{ Beban Pengumpulan Tol } & $4,101,853,485$ \\
\hline & Bebanpelayanan Pemakai & \\
$\mathbf{6}$ & Jalan Tol & $4,252,111,118$ \\
\hline & Beban Pemeliharaan Aktiva & \\
\hline $\mathbf{7}$ & Jalan & $2,021,883,661$ \\
\hline $\mathbf{8}$ & Beban Pbb & $2,835,458,968$ \\
\hline $\mathbf{9}$ & Beban Adm\&Umum & $1,016,575,754$ \\
\hline & Total Beban Usaha & $\mathbf{2 6 , 7 7 8 , 0 6 9 , 7 1 3}$ \\
\hline & (Diluar Provisi \& Depresiasi) & \\
\hline $\mathbf{1 0}$ & Beban Provisi & $11,287,365,713$ \\
\hline $\mathbf{1 1}$ & Beban Penyusutan \& Amortisasi & $17,830,972,876$ \\
\hline & Total Beban & $\mathbf{5 5 , 8 9 6 , 4 0 8 , 3 0 2}$ \\
\hline & Laba Usaha & $\mathbf{1 4 0 , 6 9 9 , 2 7 2 , 0 2 3}$ \\
\hline
\end{tabular}

Sumber : PT Jasa Marga (Persero) Tbk Cabang Purbaleunyi Tahun 2017

Berdasarkan data diatas dapat diketahui laba pada periode ini adalah sebesar $140,699,272,023$. Tingkat laba perusahaan pada periode ini sesuai dengan anggaran yang ditetapkan, sehingga laba optimal tercapai oleh perusahaan.

\section{Tingkat EfisiensiBiaya Operasional Setelah Adanya Penerapan Layanan E-Business (E-Toll Card).}

Dalam penelitian ini peneliti mendapatkan anggaran biaya operasional dengan realisasi nya selama 2 Bulan setelah adanya penerapan. 

Tabel 4

Biaya Operasional Setelah Penerapan E-Toll Card PT Jasa Marga (Persero) Tbk Cabang Purbaleunyi

\begin{tabular}{|c|l|c|r|r|c|}
\hline NO & \multicolumn{1}{|c|}{ URAIAN } & ANGGARAN & \multicolumn{1}{c|}{ REALISASI } & PROPORSI & KET. \\
\hline 1 & $\begin{array}{l}\text { Beban } \\
\text { Pengumpulan Tol }\end{array}$ & $6,194,638,203$ & $5,092,221,555$ & 0.8220 & Efisien \\
\hline 2 & $\begin{array}{l}\text { Pelayanan Pemakai } \\
\text { Jalan }\end{array}$ & $4,418,408,889$ & $5,896,878,233$ & 1.3346 & Inefisien \\
\hline 3 & $\begin{array}{l}\text { Pemeliharaan } \\
\text { Aktiva Jalan }\end{array}$ & $3,926,145,287$ & $4,206,815,748$ & 1.0715 & Inefisien \\
\hline & TOTAL & $\mathbf{1 4 , 5 3 9 , 1 9 2 , 3 7 9}$ & $\mathbf{1 5 , 1 9 5 , 9 1 5 , 5 3 6}$ & $\mathbf{1 . 0 7 6 0}$ & Inefisien \\
\hline
\end{tabular}

Sumber : PT Jasa Marga (Persero) Tbk Cabang Purbaleunyi Tahun 2017

Pada periode ini terjadi inefisiensi biaya operasional karena realisasi lebih besar dari anggaran perusahaan dengan proporsi 1.0760, hal ini disebabkan karena biaya yang di keluarkan oleh perusahaan lebih besar dari yang dianggarkan perusahaan, diantaranya beban pelayanan pemakai jalan dengan proporsi 1.3346 dan beban pemeliharaan aktiva dengan proporsi 1.0715. Dampak dari peralihan sistem pembayaran yang manual ke sistem pembayaran elektronik berimbas kepada meningkatnya biaya operasional yang harus dikeluarkan oleh perusahaan.

\section{Tingkat Laba Setelah Adanya Penerapan Layanan E-Business (E-Toll Card)}

Pengukuran besarnya laba tergantung pada besarnya pendapatan dan biaya. Analisis dilakukan terhadap Pendapatan dan Beban saat 2 bulan setelah penerapan $E$ Toll Card.

Tabel 5

Tingkat Laba Setelah Penerapan E-Toll Card

\begin{tabular}{|c|l|r|}
\hline & \multicolumn{1}{|c|}{ URAIAN } & \multicolumn{1}{|c|}{ JUMLAH } \\
\hline $\mathbf{N O}$ & \multicolumn{1}{|c|}{ Pendapatan Tol } & $357,313,576,526$ \\
\hline $\mathbf{2}$ & Pendapatan Non Tol & $5,178,728,740$ \\
\hline & Total Pendapatan & $\mathbf{3 6 2 , 4 9 2 , 3 0 5 , 2 6 6}$ \\
\hline $\mathbf{3}$ & Beban Sdm & $21,478,365,427$ \\
\hline $\mathbf{4}$ & Beban Operasi & $\mathbf{1 5 , 1 9 5 , 9 1 5 , 5 3 6}$ \\
\hline $\mathbf{5}$ & Beban Pengumpulan Tol & $5,092,221,555$ \\
\hline $\mathbf{6}$ & Bebanpelayanan Pemakai Jalan Tol & $5,896,878,233$ \\
\hline $\mathbf{7}$ & Beban Pemeliharaan Aktiva Jalan & $4,206,815,748$ \\
\hline $\mathbf{8}$ & Beban Pbb & $2,835,458,968$ \\
\hline $\mathbf{9}$ & Beban Adm\&Umum & $1,410,887,216$ \\
\hline & Total Beban Usaha & $\mathbf{4 0 , 9 2 0 , 6 2 7 , 1 4 7}$ \\
\hline & (Diluar Provisi \& Depresiasi) & \\
\hline $\mathbf{1 0}$ & BEBAN PROVISI & $15,433,110,721$ \\
\hline $\mathbf{1 1}$ & Beban Penyusutan \& Amortisasi & $42,723,338,756$ \\
\hline & Total Beban & $\mathbf{9 9 , 0 7 7 , 0 7 6 , 6 2 4}$ \\
\hline & Laba Usaha & $\mathbf{2 6 3 , 4 1 5 , 2 2 8 , 6 4 2}$ \\
\hline
\end{tabular}

Sumber : PT Jasa Marga (Persero) Tbk Cabang Purbaleunyi Tahun 2017 

Berdasarkan data diatas dapat diketahui laba pada periode ini adalah sebesar 263,415,228,642. Dimana pendapatan terbesar diperoleh dari pendapatan tol sebesar 357,313,576,526 meningkat dari periode sebelumnya dikarenakan adanya libur panjang sehingga volume kendaraan bertambah. Pendapatan non tol juga meningkat dari periode sebelumnya dikarenakan adanya pembayaran kontrak perpanjangan sewa di 9 titik iklan dan adanya kontrak sewa baru di 2 titik iklan.

\section{Perbandingan Tingkat Efisiensi Biaya Operasional Dan Kaitannya Dengan Tingkat Laba Perusahaan Saat Sebelum Dan Sesudah Penerapan Layanan E-Business (E- Toll Card).}

Berdasarkan hasil perhitungan efisiensi biaya operasional dan tingkat laba yang terjadi pada periode sebelum dan setelah penerapan layanan E-toll Card maka dapat dilakukan analisis perbandingan antara dua hal tersebut pada Tabel 4.6 dan 4.7 sebagai berikut:

Tabel 6

Perbandingan Biaya Operasional Sebelum Dan Setelah Penerapan e-toll Card

\begin{tabular}{|c|c|c|c|c|c|c|c|}
\hline \multirow{2}{*}{ NO } & \multirow{2}{*}{ URAIAN } & \multicolumn{3}{|c|}{$\begin{array}{l}\text { SEBELUM } \\
\text { PENERAPAN }\end{array}$} & \multicolumn{3}{|c|}{$\begin{array}{c}\text { SETELAH } \\
\text { PENERAPAN }\end{array}$} \\
\hline & & Anggaran & Realisasi & Proporsi & Anggaran & Realisasi & Proporsi \\
\hline 1. & $\begin{array}{l}\text { Beban } \\
\text { Pengumpulan Tol }\end{array}$ & $4,223,441,103$ & $4,101,853,485$ & 0.9712 & $6,194,638,203$ & $5,092,221,555$ & 0.8220 \\
\hline 2 & $\begin{array}{l}\text { Beban Pelayanan } \\
\text { Pemakai Jalan }\end{array}$ & 4,592,209,268 & $4,252,111,118$ & 0.9259 & 4,418,408,889 & $5,896,878,233$ & 1.3346 \\
\hline 3 & $\begin{array}{l}\text { Beban } \\
\text { Pemeliharaan } \\
\text { Aktiva Jalan }\end{array}$ & $2,105,543,545$ & $2,021,883,661$ & 0.9603 & $3,926,145,287$ & $4,206,815,748$ & 1.0715 \\
\hline & TOTAL & $10,921,193,916$ & $10,375,848,264$ & $\begin{array}{c}0.9525 \\
\text { EFISIEN }\end{array}$ & $14,539,192,379$ & $15,195,915,536$ & $\begin{array}{r}1.0760 \\
\text { IN-EFISIEN }\end{array}$ \\
\hline
\end{tabular}

Sumber : PT Jasa Marga (Persero) Tbk Cabang Purbaleunyi Tahun 2017

Berdasarkan hasil pengumpulan data biaya operasional dan tingkat laba saat sebelum dan setelah penerapan maka dapat dikatakan bahwa pada periode sebelum penerapan terjadi efisiensi biaya operasional, penggunaan biaya saat sebelum diterapkannya E-Toll Card sudah baik karena adanya pengendalian yang efektif dari segi pembiayaan, maka perusahaan mencapai target laba yang direncanakan.

Selanjutnya pada periode setelah penerapan, posisi biaya operasional dikatakan tidak efisien (inefisiensi). Hal ini terjadi akibat adanya peralihan transaksi pembayaran dari tunai menjadi non tunai pada 31 Oktober 2017. Perusahaan mengeluarkan biaya tambahan karena adanya peningkatan biaya pada pemeliharaan aktiva, biaya listrik yang bertambah, beban publikasi. Sedangkan dari segi tingkat laba, perusahaan mendapatkan pendapatan yang lebih karena tidak adanya kecurangan yang mungkin dilakukan dari petugas tol. 

Tabel 7

Perbandingan Tingkat Laba Sebelum Dan Setelah Penerapan $e$-toll Card

\begin{tabular}{|r|c|r|r|}
\hline No & \multicolumn{1}{|c|}{ Uraian } & \multicolumn{1}{c|}{$\begin{array}{c}\text { Sebelum } \\
\text { Penerapan }\end{array}$} & \multicolumn{1}{c|}{$\begin{array}{c}\text { Setelah } \\
\text { Penerapan }\end{array}$} \\
\hline 1 & Pendapatan Tol & $194,471,282,144$ & $357,313,576,526$ \\
\hline 2 & Pendapatan Non Tol & $2,124,398,181$ & $5,178,728,740$ \\
\hline \multicolumn{2}{|c|}{ Total Pendapatan } & $196,595,680,325$ & $362,492,305,266$ \\
\hline 3 & Beban Sdm & $12,550,186,727$ & $21,478,365,427$ \\
\hline 4 & Beban Operasi & $10,375,848,264$ & $15,195,915,536$ \\
\hline 5 & Beban Pengumpulan Tol & $4,101,853,485$ & $5,092,221,555$ \\
\hline 6 & Beban Pely.Pemakai Jalan Tol & $4,252,111,118$ & $5,896,878,233$ \\
\hline 7 & Beban Pemeliharaan Aktiva Jalan & $2,021,883,661$ & $4,206,815,748$ \\
\hline 8 & Beban Pbb & $2,835,458,968$ & $2,835,458,968$ \\
\hline 9 & Beban Adm\&Umum & $1,016,575,754$ & $1,410,887,216$ \\
\hline \multicolumn{2}{|c|}{ Total Beban Usaha } & $26,778,069,713$ & $40,920,627,147$ \\
\hline 10 & Beban Provisi & $11,287,365,713$ & $15,433,110,721$ \\
\hline 11 & Beban Penyusutan \& Amortisasi & $17,830,972,876$ & $42,723,338,756$ \\
\hline \multicolumn{2}{|r|}{ Total Beban } & $55,896,408,302$ & $99,077,076,624$ \\
\hline Laba Usaha & $140,699,272,023$ & $263,415,228,642$ \\
\hline
\end{tabular}

Sumber : PT Jasa Marga (Persero) Tbk Cabang Purbaleunyi Tahun 2017

Berdasarkan hasil pengumpulan data biaya operasional dan tingkat laba saat sebelum dan setelah penerapan maka dapat dikatakan bahwa pada periode sebelum penerapan terjadi efisiensi biaya operasional, penggunaan biaya saat sebelum diterapkannya E-Toll Card sudah baik karena adanya pengendalian yang efektif dari segi pembiayaan, maka perusahaan mencapai target laba yang direncanakan.

Selanjutnya pada periode setelah penerapan, posisi biaya operasional dikatakan tidak efisien (inefisiensi). Hal ini terjadi akibat adanya peralihan transaksi pembayaran dari tunai menjadi non tunai pada 31 Oktober 2017. Perusahaan mengeluarkan biaya tambahan karena adanya peningkatan biaya pada pemeliharaan aktiva, biaya listrik yang bertambah, beban publikasi. Sedangkan dari segi tingkat laba, perusahaan mendapatkan pendapatan yang lebih karena tidak adanya kecurangan yang mungkin dilakukan dari petugas tol.

Pada 2 (dua) bulan setelah penerapan E-Toll Card memang belum terlihat efisiensi dari segi biaya operasional karena masih berada pada masa transisi, sehingga biaya pun wajar bila terjadi kenaikan. Namun dalam segi efisiensi waktu, penerapan ini memangkas waktu transaksi dan antrian di gerbang tol menjadi lebih cepat karena hanya membutuhkan waktu 2-3 detik saja. Adanya kemudahan yang diberikan oleh pihak perusahaan tentu memberikan keuntungan bagi para penggunanya. Namun demikian dari jangka waktu dua bulan setelah penggunaan E-Toll Card ini ternyata masih banyak masyarakat sebagai pengguna yang belum mendapatkan informasi terkait fasilitas tersbut dan dimana tempat untuk mengakses atau mendapatkan E-Toll Card tersebut. Hal ini dapat dikarenakan masih minimnya sosialisasi dan promosi yang dilakukan oleh PT Jasa Marga Tbk melalui berbagai media sosialisasi seperti channel You Tube atau membuat iklan yang mengedukasi melalui TV, dll. 



\section{E. Kesimpulan \& Saran}

\section{Kesimpulan}

1. Penerapan E-Toll Card pada PT Jasa Marga Tbk Cabang Purbaleunyi sudah memadai.

2. Terjadi efisiensi biaya operasional sebelum adanya penerapan E-Toll Card.

3. Tingkat laba tercapai sebelum adanya penerapan E-Toll Card.

4. Terjadi inefisiensi biaya operasional akibat adanya peralihan sistem pembayaran dari tunai ke non tunai.

\section{Saran}

Bagi perusahaan sebaiknya melakukan penyampaian informasi yang lebih efektif dan mengedukasi bagi pengguna tol, dengan dibuatkan iklan versi film singkat di Youtube \& TV, melakukan evaluasi kebijakan mengenai biaya operasi agar tidak terjadi inefisiensi biaya, akses kartu ditambah dilokasi terdekat, dan kartu tersedia bagi selain nasabah BUMN.

Bagi peneliti selanjutnya dapat menambah data keuangan menjadi pertahun agar data yang disajikan lebih kuat.

\section{F. Daftar Pustaka}

Amalia, G.P. \& E.H. Fanida. 2017. "Efektivitas Electronic Toll (e-toll) Oleh PT Jasa Marga Surabaya" dalam E-Journal UNESA, Vol. 5 Iss 2 pp.4.

Chaffey, Dave. 2009. E-Business And E-Commerce Management: Strategy, Implementation And Practice Fourth Edition. London: Pranctice Hall.

Combe, Collin. 2006. Introduction to E-Business Management And Strategy. London: Elsevier.

Govindarajan, Anthony. 2005. Sistem Pengendalian Manajemen. Jakarta: Salemba Empat.

Hansen, D.R. \& M.M Maryanne. 2009. Akuntansi Biaya. Jakarta: Salemba Empat.

Indrajit, Richardus. Eko. 2002. Konsep dan Strategi E-Business. Jakarta: Aptikom.

Lukaman, Raddy. R. 2017. Mulai Hari Ini Bayar Tol Tak Bisa Pakai Uang Tunai, tersedia di www.liputan6.com [31/10/2017].

Mulyadi. 2009. Akuntansi Biaya. Yogyakarta: UPP STIM YKPN.

Santoso, Wimboh. 2017. Wimboh Akan Fokus Efisiensi Anggaran dan Operasional OJK, tersedia di www.katadata.co.id [09/06/2017].

Subramanyam, K.R. \& J. J .Wild. 2010. Analisis Laporan Keuangan. Jakarta: Salemba Empat.

Suyanto, Muhammad. 2003. Strategi Periklanan pada E-Commerce Perusahaan Top Dunia. Yogyakarta: Andi Publisher.

Wijaya, Y. O. \& L. Syafitri. 2013. "Analisis Pengendalian Biaya Produksi Dan Pengaruhnya Terhadap Laba Pabrik Penggilingan Srikandi Palembang" dalam Jurnal Akuntansi Vol.2. 